УДК 159.98:331.005.95/

DOI https://doi.org/10.26661/2310-4368/2020-2-4

\title{
ЗАДОВОЛЕНОСТЬ ФУНКЦІОНУ ВАННЯМ ТА СОЦІАЛЬНА ФРУСТРОВАНІСТЬ СЕРЕДНЬОГО МЕДИЧНОГО ПЕРСОНАЛУ, ЯКИЙ ПРАЦЮЄ В УМОВАХ ПІДВИЩЕНОЇ СТРЕСОГЕННОСТІ (3 ВЕТЕРАНАМИ АТО/ООС)
}

\author{
Лапінська Т. В. \\ аспірантка кафедри психології \\ Інститут підготовки кадрів державної служби зайнятості України \\ вул. Нововокзальна, 17, Київ, Україна \\ orcid.org/0000-0001-8963-2087 \\ lawh@ukr.net
}

\begin{abstract}
Ключові слова: фрустрачія, задоволеність функиіонуванням (ЗФ), соиіальна фрустрованість (СФ), професійне вигорання (ПВ), середній медичний працівник (СМП), стресогенність.
\end{abstract}

Стаття присвячена аналізу рівня задоволеності функціонуванням у різних сферах життєдіяльності та пов'язаних з нею чинників, які мають найбільший вплив на рівень задоволеності, а також визначення ступеня соціальної фрустрованості середніх медичних працівників, які працюють в умовах підвищеної стресогенності (з ветеранами АТО/ООС). Розкрито основні етапи дослідження, методи та методики, які використовувалися на кожному з цих етапів. Проаналізований вплив сфер життєдіяльності на рівень задоволеності СМП та їх ступінь соціальної фрустрованості і $є$ однією з причин розвитку професійного/емоційного вигорання в умовах підвищеної професійної стресогенності. Натепер життя людини в суспільстві наповнене різного масштабу обмеженнями, складнощами та психологічними бар' єрами. На шляху до задоволення своїх базових потреб, які грають особливу роль у детермінації поведінки і діяльності людей, медичний працівник стикається 3 ними і це викликає в нього певні емоційні реакції та стани, які отримали назву фрустрація. Професійна діяльність СМП відрізняється від інших сфер: дефіцит часу на обміркування та прийняття правильного рішення, висока відповідальність за виконання поставлених завдань. Останнім часом радикальні зміни у суспільстві та в медичних закладах додають додаткового психологічного навантаження на медичних працівників, що пов'язані не тільки з необхідністю виконання роботи на високому професійному рівні, а й насамперед 3 підвищеним стресовим навантаженням внаслідок тісної взаємодії з пацієнтами - ветеранами АТО/ООС. Процес дезадаптації особистості призводить до деструктивних змін, які породжують деформацію поведінки людини у соціальній сфері. Дезадаптуючим можна називати такий хід внутрішньопсихічних процесів і поведінки людини, що призводить не до розв’язання проблемної ситуації, а до ії поглиблення, до посилення труднощів і тих неприємних переживань, які вона викликає. Саме соціальна дезадаптованість та психологічна нестійкість у сучасних реаліях життя виводить на новий рівень проблему фрустрації та іiі вплив на розвиток особистості, що і зумовило актуальність такої теми. 


\title{
SATISFACTION OF NURSES WORKING IN CONDITIONS OF INCREASED STRESS (WITH ANTI-TERRORIST OPERATION VETERANS) WITH THE FUNCTIONING AND SOCIAL FRUSTRATION
}

\author{
Lapinska T. V. \\ Postgraduate Student at the Department of Psychology \\ Ukrainian State Employment Service Training Institute \\ Novovokzalna str., 17, Kyiv, Ukraine \\ lawh@ukr.net \\ orcid.org/0000-0001-8963-2087
}

\begin{abstract}
Key words: frustration, satisfaction with functioning $(S F)$, social frustration $(S F)$, professional burnout $(P B)$, nursing staff, stress.
\end{abstract}

\begin{abstract}
The article is devoted to the analysis of the level of satisfaction with functioning in various spheres of life and related factors that have the greatest impact on the level of satisfaction, as well as determining the degree of social frustration of nurses working in high stress (with war veterans). The main stages of the research, methods and techniques used at each of these stages are revealed. The influence of the spheres of life on the level of satisfaction of nursing staff and their degree of social frustration is analyzed, and is one of the reasons for the development of professional/emotional burnout in conditions of increased professional stress. Today, human life is filled with various limitations, difficulties and psychological barriers. On the way to meeting basic needs, which play a special role in determining the behaviour and activities of people, the health worker encounters them and this causes him certain emotional reactions and conditions, which are called frustration. The professional activity of nurses differs from other areas: lack of time to think and make the right decision, high responsibility for the tasks. Recently, radical changes in society and in medical institutions add additional psychological burden on health workers, which is associated not only with the need to perform work at a high professional level, but also with increased stress due to close interaction with patients-veterans of Anti-terrorist operation. The process of personality maladaptation leads to destructive changes that cause a deformation of human behaviour in the social sphere. Such a course of intrapsychic processes and human behaviour can be called maladaptive, which does not lead to the solution of the problem situation, but to its deepening, to the intensification of difficulties and those unpleasant experiences that it causes. It is social maladaptation and psychological instability that brings the problem of frustration and its impact on the development of personality to a new level, which led to the relevance of this topic.
\end{abstract}

Постановка проблеми. Психологічна готовність середніх медичних працівників (далі-СМП) до професійної діяльності - основа задоволеності функціонуванням та соціальної фрустрації, особливо в умовах підвищеної стресогенності (роботи з ветеранами АТO/OOC). Психологічні аспекти трудової діяльності середніх медичних працівників стоять у ряду важливих і маловивчених проблем теоретичної та прикладної психології. Відомо, що рівновага між людиною і професійним середовищем, досягнута в процесі професійної адаптації, не є чимось статичним. Зміна умов праці, потреб, можливостей і цілей можуть викликати серйозні зміни у професійному функціонуванні і призвести до виникнення такого явища, як професійне вигорання. Основним проявом психологічної зрілості в професійній діяльності $€$ здатність вчасно діагностувати і керувати негативними психічними станами. Одним iз таких психологічних феноменів є фрустрація. Фрустрація - це психічний стан, який виражається в характерних рисах переживань і поведінки i викликається об'єктивно нездоланними (або такими, що суб' єктивно сприймаються як нездоланні) труднощами, які виникають на шляху до досягнення мети чи до вирішення задачі. Галузь системи охорони здоров'я України останніми роками постійно реформується, змінюється, що не може не відображатися на умовах праці середніх медичних працівників, які опікуються лікуванням 
та реабілітацією ветеранів АТО/OОС. Специфіка роботи, що може виступати в ролі фрустратора, передбачає необхідність виконання професійних обов'язків у більш важких, ускладнених умовах, під впливом емоційних і стресових факторів, пов'язаних з обслуговуванням особливої категорії населення - ветеранів АТО/OOC. Це все не може не впливати на психічний та фізичний стан медичного персоналу. Досить часто підвищена професійна стресогенність супроводжується зниженням психологічного резерву організму і призводить до порушень життєдіяльності, несприятливих особистісних змін, які в майбутньому призводять до незадоволеності власним функціонуванням у різних сферах, що негативно позначається на загальному та психологічному стані здоров'я, працездатності, стосунках з оточенням і закінчується пригніченістю та розчаруванням.

Метою статті $\epsilon$ вивчення рівня професійного вигорання у СМП, рівень задоволеності функціонуванням у різних сферах, соціальної фрустрованості у СМП, які працюють в умовах підвищеної професійної стресогенності (з ветеранами АТО/ OOC), для подальшого розроблення заходів психокорекції та психопрофілактики.

Завдання дослідження - встановити рівень задоволеності функціонуванням у різних сферах та діагностувати рівень соціальної фрустрованості у середнього медичного персоналу, що працює в умовах підвищеної професійної стресогенності (з ветеранами ATO/OOC).

Аналіз останніх досліджень і публікацій. Вивчаючи першоджерела дослідження фрустрації, необхідно відзначити, що термін «фрустрація» застосовується у сучасній науковій літературі в різних значеннях. Часто під цим терміном мають на увазі форму емоційного стресу або можуть розглядати як одну із форм психологічного стресу. У такому разі потрібно звернутися до опису самого поняття «фрустрація». $\mathcal{C}$ різні гіпотези теоретичного обгрунтування цього феномена, але одним із перших, хто звернув увагу на феномен фрустрації, був Зігмунд Фрейд. Створення психоаналітичної теорії, в якій він розглядав фрустрацію в рамках внутрішньо-особистісного конфлікту, як боротьбу двох складників психіки людини «ід» і «суперего», своєрідну реакцію на вимушену відмову від несвідомих потягів «ід» на користь суспільних норм та цінностей. У ранніх роботах 3. Фрейда, який зазначав, що якщо об'єкт $€$ джерелом неприємних відчуттів, то це в кінцевому рахунку може призвести до агресивних нахилів проти об'єкта [1, с. 112-113]. Так сформувалася теза про те, що поява агресії завжди передбачає існування фрустрації i, навпаки, що існування фрустрації завжди призводить до певної форми агресії. Поява стану фрустрації та тієї чи іншої форми реагування залежить від особистісних якостей людини. Так, психологи використовують термін «фрустраційна толерантність», тобто стійкість до фрустраторів. Варто навести думку Л. Берковіц, який вказує на те, що фрустрація провокує тенденцію до агресії. Відповідно до традиційної схеми біхевіоризму «S-R» фрустрація розглядається як причина, агресія - наслідок, причому однозначний і неминучий [2, с. 45-47]. Найбільш яскраво фрустраційна теорія агресії сформульована Джоном Доллардом. Згідно з цією теорією, агресія не $є$ наслідком внутрішніх потреб, а $€$ наслідком фрустрації, тобто перепон, що виникають на шляху цілеспрямованих дій суб'єкта або ненастання очікуваного стану, якого прагне суб'єкт. Тому Д. Доллардом висувались два положення: 1) агресія завжди є наслідком фрустрації; 2) фрустрація завжди тягне за собою агресію. Однак ця теорія не підтвердилась. Як пише Ганс Хекхаузен: «Не будь-яка агресія виникає внаслідок фрустрації (зокрема, з фрустрацією не пов'язана жодна 3 форм інструментальної агресіі) [3, с. 234-236]. Варто відзначити думку дослідника Л. Берковіца, який вказував на те, що фрустрація пов'язана 3 очікуваннями мети, а не 3 iï фактичним досягненням. Тобто якщо мета $є$ недосяжною, то фрустрація напряму пов'язана з крахом надій на іiі досягнення і в результаті тільки створює загальне емоційне збудження та провокує тенденцію до агресії лише тією мірою, якою несе негативний вплив. Він додає дві важливі змінні до вже відомого рівняння: гнів як збуджуючий компонент і пусковий подразник, що запускають агресивну реакцію. Наявність останніх вважається обов'язковою, на думку A. Cohen, обов'язкове створення спеціальних факторів i обставин, які у своїй сукупності можуть провокувати агресивну реакцію на фрустраційну ситуацію, і тільки наявність відповідних умов і обставин зробить реакцію на фрустрацію агресивною [4]. Фрустрація (лат. frustratio - відчуття обману, краху) - психічний стан людини, що є наслідком непереборних труднощів на шляху до мети або до вирішення завдань [5]. Проявляється цей стан насамперед у почутті розчарування і супроводжується напруженістю, тривожністю, інколи навіть відчаєм, почуттям безвиході, депресією. Зважаючи на те, що для виникнення фрустраційної ситуації необхідна сильна мотивація досягнення мети і наявність перешкоди щодо іï досягнення, фрустраційні ситуації класифікуються за характером фрустраційних мотивів i за характером «бар'єрів» [6]. Спираючись на теорію А. Маслоу [7], до класифікації першого типу належать вроджені і набуті психологічні потреби. Щодо діяльності медичного працівника, то фрустрація носить патогенний характер і зводиться до праг- 
нення поваги і загального схвалення керівництва та особового внеску до розвитку медицини в стресогенних ситуаціях. Бар'єри в такому разі можуть бути: фізичними (недостатнє матеріальне забезпечення, залежність від умов праці і т. п.); біологічними (вік, стаж роботи, стан здоров'я); психологічними (страх спілкування 3 ветеранами АТО/ OOC, брак знань і умінь роботи в умовах підвищеної стресогенності); соціокультурними (особливий контингент хворих, соціальна група ветерани АТО/ООС). За допомогою певних вольових зусиль можливе подолання фрустраційних ситуацій. У такому разі доречно замість терміна «ситуація фрустрації» використовувати поняття «ситуація ускладнення» [8]. Говорити про те, що людина перебуває у ситуації фрустрації можна в тому разі, якщо труднощі не вирішені чи вирішені, але зі значними відхиленнями від головної мети. Фрустрована людина відчуває занепокоєння, напругу і втрату інтересу, стан апатії, байдужості, провини і тривоги, люті, ворожості, заздрості, особливо в умовах підвищеної професійної стресогенності (з ветеранами АТО/ OОC). У монографії Н. Майера [9] «Фрустрація: поведінка без мети» поведінка фрустрованої людини характеризується як така, що не має цілі, у зв'язку із втратою цільової орієнтації. Прикладом подібної поведінки стосовно діяльності середнього медичного працівника в умовах підвищеної стресогенності (з ветеранами АТО/ООС) може бути відсутність взаєморозуміння, створення конфліктних ситуацій, зниження професіоналізму, що не дає змоги досягти бажаного результату. Фрустраційно спровокована поведінка у цьому разі мотивована новою метою - технічно відпрацювати необхідний час. Важливо те, що досягнення цієї нової мети позбавлене сенсу i веде до невдачі [10]. Ступінь прояву негативних реакцій людини на фрустрацію (агресія, відмова, негативізм тощо) залежить від індивідуального діапазону реактивності і меж працездатності кожної людини. За умов виходу за ці межі можлива поява нестійкої психічної діяльності, виникнення внутрішнього чи зовнішнього конфлікту [11]. Ознаки агресивного характеру, які спровоковані фрустрацією, частіше спостерігаються у осіб, не досить вихованих, нестримних у прояві емоцій, грубих з оточуючими. Депресивні реакції у разі фрустрації більш поширені у осіб невротичного складу, тривожно-недовірливих, невпевнених у собі. Крім агресивної фрустрації, спрямованої на зовнішні об' єкти, перешкоди, інших людей, може виявлятися регресивна фрустрація, спрямована на самого себе (людина звинувачує саму себе за невдачі, за нездатність подолати труднощі). Якщо людина тривалий час не виходить із фрустраційного стану, то можуть виникнути неусвідомлю- вані мотиви поведінки та сформуватися спотворені риси особистості (заздрісність стосовно інших людей або надмірно занижена самооцінка, комплекс неповноцінності). 3'являються поодинокі дослідження, де фрустрація вивчається в рамках психології емоцій. Зокрема, К. Ізард порушує питання стосовно можливої взаємозалежності і зумовленості фрустраційних та емоційних станів [12]. Однак, аналізуючи дослідження радянських авторів, можна зазначити, що така проблема так i не стала предметом цілісного вивчення. Вона так і залишилася на рівні тенденційного розгляду у контексті інших психологічних явищ та факторів. Тут психічна діяльність розглядається ширше ніж тільки низка змінних параметрів і властивостей особистості. Акцент робиться на складності i багатовекторності будови, що становить психічну діяльність людини. Фрустраційні ж стани займають проміжне становище. Цій проблемі присвячені дослідження одразу декількох психологів [13]. Л. Куліков [14], М. Левітов [15], В. Мясищев [16], К. Максименко [17], О. Прохоров [18], Ю. Сосновікова [19], В. Юрченко [20] та інші запропонували авторські підходи до розуміння динаміки психічних станів, однак у своїй більшості вони беруть за основу визначення М. Левітова. Інший вектор вивчення поведінкових змін - міждисциплінарний характер проблеми фрустраційних станів, який виражається у появі робіт, присвячених інтеграційним зв'язкам між психологічними та медичними дослідженнями. Зокрема, у роботах Г. Пріба фрустрація розглядається як чинник соціальної дезадаптації у пацієнтів 3 психічними розладами [21]. Українська дослідниця Т. Гаряча на новий рівень виводить питання соматогенної фрустрації. Цікавість викликає розроблений нею комплекс психокорекційних заходів для осіб із соматогенною фрустрацією. У іiі роботах виявлено чинники психічного здоров'я у вищезазначених осіб та встановлено ієрархію їх змін під впливом психокорекційних заходів [22].

Матеріал та методи дослідження. Базами емпіричного дослідження стали: госпіталі ветеранів війни КУ «Обласний госпіталь для ветеранів війни Житомирської обласної ради», К3 «Кіровоградський обласний госпіталь ветеранів війни», КУ «Обласний медичний центр вертебрології і реабілітації Житомирської обласної ради». Шляхом анонімного опитування охоплено 130 жінок - досліджувана група (ДГ), віком 21-58 р. У респондентів виявлений рівень задоволеності функціонуванням різного ступеня вираженості за допомогою опитувальника «Ступінь задоволеності власним функціонуванням у різних сферах», розробленого I. Karler в адаптації Б. Карвасарського, та рівень соціальної фрустрованості- 
за однойменним опитувальником Л. Вассермана в модифікації В. Бойка. Дослідження проводилося 3 дотриманням принципів добровільності, інформованості та конфіденційності. За віком респонденти становили три групи: I - 21-25 р. (ДГ1) ; II26-50 p. (ДГ2); III - більше 50 р. (ДГ3). Середній вік становить 39,5 року. За стажем роботи респонденти поділялися на чотири групи: I - до 5 p. (ДГ1С); II - 6-15 р. (ДГ 2C); III - 16-25 р. (ДГЗС); IV - більше 25 p. (ДГ4С). Середній стаж роботи 18,2 року.

Методи дослідження: загальнотеоретичні: міждисциплінарний аналіз і синтез літератури 3 проблеми дослідження; порівняння, систематизація, узагальнення, інтерпретація наявних теоретичних підходів та емпіричних результатів. Психодіагностичні методи. Задоволеність функціонуванням визначали із використанням опитувальника «Ступінь задоволеності власним функціонуванням у різних сферах», розробленого I. Karler в адаптації Б. Карвасарського [23], рівень соціальної фрустрованості - за однойменним опитувальником Л. Вассермана в модифікації В. Бойка [24]. Для обробки статистичних даних застосовувалися табличний процесор MS Excel v.16.0 та IBM SPSS Statistics 20. Для обробки емпіричних даних використовувалися методи описової статистики, для вимірювання ступеня кореляційної залежності - кореляційний аналіз (коефіцієнт Пірсона).

Виклад основного матеріалу дослідження 3 обгрунтуванням отриманих результатів. За результатами дослідження можна зазначити, що здебільшого СМП, який працює в умовах підвищеної професійної стресогенності $з$ ветеранами ATO/OOC, має проблеми в декількох сферах функціонування. Також ми виявили поведінкові реакції, які не завжди інтерпретуються, або ті, котрі СМП не хотів описувати чи пояснювати. На першому етапі ми проводили діагностику рівня задоволеності функціонуванням середніх медичних працівників (із використанням опитуваль- ника «Ступінь задоволеності власним функціонуванням у різних сферах», розробленого I. Karler в адаптації Б. Карвасарського) і визначали за оцінкою такі сфери їхньої життєдіяльності та встановлювали джерела життєвих труднощів, як: подружнє життя; стосунки 3 родичами; професійна сфера; соціальна сфера (табл. 1).

Вивчення у респондентів (за віковими критеріями) ступеня задоволеності власним функціонуванням, 3 визначенням джерел труднощів у різних сферах життедіяльності, показало таке: найбільш виражений рівень незадоволеності своїм функціонуванням для СМП виявлено в групі ДГ2, а саме професійна сфера та сімейні стосунки. Обстежені в ДГ1 і ДГЗ зазначали, що саме професійна сфера мала суттєвий вплив на формування в них ПВ. Обстежені часто як причину стресу виділяли конфліктні стосунки з колегами, ветеранами АТО/OОC та членами їхніх родин, незадоволеність фінансовим станом. Крім того, значний вплив на виникнення професійного вигорання має така сфера функціонування, як стосунки 3 родичами, найвищий рівень незадоволеності в ДГ2 (такі внутрішньосімейні розлади, як неправильний розподіл сімейних обов'язків, ставлення до фінансів тощо), що також сприяе формуванню синдрому професійного вигорання. Особливістю ПВ у обстежуваних ДГ1 та ДГЗ $є$ нездатність виділити провідну сферу життєдіяльності, яка б найбільше впливала на розвиток емоційного/професійного вигорання. В більшості обстежених проблеми існували у кількох сферах функціонування: у сімейних стосунках, у професійній діяльності, у спілкуванні з родичами, що загалом формувало софакторність сфер функціонування. Причому слід зазначити, що великого значення обстежувані в ДГ1 надавали питанням матеріального благополуччя та емоційно-психологічним питанням, а обстежувані в ДГ2 та ДГЗ вважали, що сімейно-побутові ситуації та матеріальне благополуччя $\epsilon$ вагомими в розвитку ПВ, а несуттєвими є багатоплановість та монотонність

Таблиця 1

Розподіл сфер функціонування (опитувальник «Ступінь задоволеності власним функціонуванням у різних сферах», розроблений I. Karler в адаптації Б. Карвасарського)

\begin{tabular}{|l|c|c|c|c|c|c|c|c|}
\hline \multirow{2}{*}{$\begin{array}{c}\text { Сфера } \\
\text { функціонування }\end{array}$} & \multicolumn{9}{|c|}{ Вікові групи } & \multicolumn{2}{c|}{ Всього } \\
\hline & \multicolumn{2}{|c|}{ ДГ1 } & \multicolumn{2}{c|}{ ДГ2 } & \multicolumn{2}{c|}{ ДГ3 } & & N \\
\hline & $\mathrm{N}$ & $\%$ & $\mathrm{~N}$ & $\%$ & $\mathrm{~N}$ & $\%$ & $\mathrm{~N}$ & $\%$ \\
\hline Подружнє життя & 14 & 13,57 & 75 & 21,12 & 23 & 19,57 & 112 & 19,86 \\
\hline Стосунки з родичами & 14 & 14,50 & 75 & 19,53 & 23 & 17,83 & 112 & 18,55 \\
\hline Професійна сфера & 14 & 16,07 & 75 & 21,67 & 23 & 19,78 & 112 & 20,58 \\
\hline Соціальна сфера & 14 & 15,93 & 75 & 18,29 & 23 & 18,74 & 112 & 18,09 \\
\hline Сума труднощів & 14 & 60,07 & 75 & 80,61 & 23 & 75.91 & 112 & 77,08 \\
\hline
\end{tabular}


професійної діяльності. В наступній таблиці розподіл сфер функціонування вивчався в групах, де за основу розподілу брався стаж роботи (ДГ1С, ДГ2С, ДГзС, ДГ4С) (табл. 2).

Найбільш виражений рівень незадоволеності своїм функціонуванням серед СМП виявлено в групах ДГ2С та ДГЗС, а саме професійна сфера та сімейні стосунки. Респонденти зазначали, що саме труднощі, конфлікти 3 колегами та підлеглими, відсутність взаєморозуміння у сім'ї мали суттєвий вплив на формування в них ПВ. Обстежені в ДГ1С і ДГ4С не змогли виділити провідну сферу життєдіяльності, яка б відігравала основну роль у розвитку психотравми.

Наступним етапом діагностики стало вивчення рівня соціальної фрустрованості із застосуванням однойменної методики (діагностика рівня соціальної фрустрованості Л. Вассермана), яка дає можливість оцінити ступінь невдоволеності соціальними досягненнями в основних (20 параметрах) аспектах життєдіяльності. Загальний рівень соціальної фрустрованості визначався з урахуванням середнього балу за кожним пунктом, що дало змогу оцінити загальний рівень соціальної фрустрованості від 0-0,5 бала (відсутній), 3,5-4 бали (дуже високий рівень соціальної фрустрованості).

Вивчення соціальної фрустрованості у СМП у вікових групах довело більшу вираженість фрустраційного стану серед респондентів ДГ1 і ДГ2 стосовно ДГЗ. Високий показник повної незадоволеності визначався щодо матеріального становища, обстановки в суспільстві, медичного обслуговування. Серед респондентів ДГ1 відповіді в $57,1 \%$ випадків відповідали повній незадоволеності функціонуванням. У ДГ2 54,3\% випадків відповідало рівню «скоріше незадоволений», а серед ДГЗ 26,5\% відповідей свідчило про рівень «скоріше задоволений». У групах за стажем роботи встановлено, що відповідь «повністю незадоволені» в ДГС1 і ДГС3 пов'язана 3 матеріальним аспектом, тоді як у ДГС32 та ДГС4 на першому місці був саме професійний компонент, що і формував соціальну фрустрацію.

Висновки. Узагальнюючи, можна зазначити, що рівень професійного (емоційного) вигорання загалом серед СМП, які працюють в особливих умовах, а саме в умовах підвищеної професійної стресогенності (з ветеранами АТО/ OOC), $є$ нерівномірним. Встановлено, що залежно від віку та стажу роботи СМП застосовують різні механізми психологічного захисту на вплив психотравмуючих чинників на роботі. Виявлено, що у середніх медичних працівників низький рівень соціальної фрустрації, що свідчить про адекватне сприйняття себе в професійному середовищі та нормальну взаємодію у суспільстві. Досліджено, що такі сфери життєдіяльності особистості, як матеріальне становище, медичне обслуговування, події в суспільстві й державі, вказують на високий рівень соціальної фрустрації в групах ДГ1, ДГ2. Аналізуючи результати у респондентів у ДГС1, ДГС2, ДГС3, ДГС4, можна зазначити, що фрустраційна поведінка переважно пов'язана 3 матеріальним та професійним аспектом.

Отже, базуючись на даних аналізу задоволеності функціонування в різних сферах життєдіяльності та рівня і структури соціальної фрустрації обстежених, нами визначено, які аспекти можуть провокувати виникнення стану фрустрації. Проаналізувавши отримані результати, ми визначили, що найбільш фруструючими для СМП, які працюють в умовах підвищеної професійної стресогенності, є обстановка у суспільстві й державі, матеріальний стан сім'ї, медичне обслуговування. Найменш фруструючими для СМП, за даними нашого дослідженням, є взаємини з дітьми, колегами, суб'єктами праці та рівень освіти.

Перспективами подальшого дослідження у такому напрямі $\epsilon$ аналіз персонологічних особливостей та визначення рівня акцентуацій у СМП, які працюють в умовах підвищеної професійної стресогенності (з ветеранами АТО/ООС).

Таблиця 2

Розподіл сфер функціонування (опитувальник «Ступінь задоволеності власним функціонуванням у різних сферах», розроблений I. Karler в адаптації Б. Карвасарського)

\begin{tabular}{|c|c|c|c|c|c|c|c|c|c|c|}
\hline \multirow[t]{3}{*}{$\begin{array}{c}\text { Сфера } \\
\text { функціону-вання } \\
\end{array}$} & \multicolumn{8}{|c|}{ Групи за стажем } & \multirow{2}{*}{\multicolumn{2}{|c|}{ Всього }} \\
\hline & \multicolumn{2}{|c|}{ ДГ1С } & \multicolumn{2}{|c|}{ ДГ2C } & \multicolumn{2}{|c|}{ ДГзС } & \multicolumn{2}{|c|}{ ДГ4С } & & \\
\hline & $\mathbf{N}$ & $\%$ & $\mathbf{N}$ & $\%$ & $\mathbf{N}$ & $\%$ & $\mathbf{N}$ & $\%$ & $\mathbf{N}$ & $\%$ \\
\hline Подружнє життя & 16 & 15,56 & 40 & 21,18 & 32 & 20,91 & 26 & 19,19 & 114 & 19,86 \\
\hline $\begin{array}{l}\text { Стосунки з } \\
\text { родичами }\end{array}$ & 16 & 15,94 & 40 & 19,88 & 32 & 19,06 & 26 & 17,31 & 114 & 18,55 \\
\hline Професійна сфера & 16 & 17,81 & 40 & 23,10 & 32 & 19,31 & 26 & 20,00 & 114 & 20,58 \\
\hline Соціальна сфера & 16 & 17,50 & 40 & 19,30 & 32 & 16,84 & 26 & 18,07 & 114 & 18,09 \\
\hline Сума труднощів & 16 & 66,81 & 40 & 83,45 & 32 & 76,13 & 26 & 74,54 & 114 & 77,03 \\
\hline
\end{tabular}




\section{ЛІТЕРАТУРА}

1. Фрейд 3. Психология бессознательного. Санкт-Петербург : Питер, 2010. 400 с.

2. Берковиц Л. Агрессия: причины, последствия и контроль. Санкт-Петербург : Прайм-Еврознак, $2001.512 \mathrm{c}$.

3. Хекхаузен Х. Мотивация и деятельность: в 2 т. Москва : Педагогика, 1986. Т. 1. 408 с.

4. Cohen A. Social norms, arbitrariness of frustrations, and status of the agent of frustration in the frustrationaggression hypothesis. Journal of Abnormal and Social Psychology. 1955. Vol. 51. No. 2. Pp. 222-226.

5. Психология труда, профессиональной, информационной и организационной деятельности (реклама, управление, инженерная психология и эргономика) : словарь / авторы-сост. Б.А. Душков, Б.А. Смирнов, А.В. Королев ; под ред. Б.А. Душкова; прил. Т.А. Гришиной. 2-е изд., доп. и перераб. Москва : Академический Проект; Екатеринбург : Деловая книга, 2003. 848 с.

6. Василюк Ф.Е. Психология переживания. Москва : МГУ, 1984. 200 с.

7. Маслоу А. Мотивация и личность. Санкт-Петербург : Питер, 2006. 352 с.

8. Василюк Ф.Е. Психология переживания. Москва : МГУ, 1984. 200 с.

9. Maier N.R.B. Frustration theory: restatement and extention. Psychological review, 1956, Vol. 63, No. 6, pp. $370-388$.

10. Василюк Ф.Е. Психология переживания. Москва : МГУ, 1984. 200 с.

11. Лебедев В.И. Личность в экстремальных условиях. Москва : Политиздат, 1989. 304 с.

12. Изард К. Психология эмоций / пер. с англ. В. Мисник, А. Татылбаева. Санкт-Петербург : Питер, 2007. $460 \mathrm{c}$.

13. Ганзен В.А. Системные описания в психологии. Ленинград : Издательство Ленинградского университета, 1984. $187 \mathrm{c}$.

14. Куликов Л.В. Проблема описания психических состояний. Психические состояния : хрестоматия. Санкт-Петербург : Питер, 2000. С. $11-43$.

15. Левитов Н.Д. О психических состояниях человека. Москва : Просвещение, 1964. 360 с.

16. Мясищев В.Н. Личность и неврозы. Ленинград : Издательство Ленинградского университета, 1960. $423 \mathrm{c}$.

17. Максименко К.С. Переживання негативних психічних станів особистістю : методичний посібник для студентів вищих навчальних закладів. Київ : КММ, 2011. 184 с.

18. Прохоров А.О. Психические состояния и их проявления в учебном процессе. Казань : Издательство Казанского университета, 1991. 163 с.

19. Сосновикова Ю.Е. Психические состояния человека, их классификация и диагностика. Горький : ГГПИ им. А.М. Горького, 1975. 118 с.

20. Юрченко В.М. Психічні стани людини: системний опис : монографія. Рівне : Оперативна поліграфія ПП Самборський I.O., 2006. 574 с.

21. Пріб Г.А. Фрустрація як чинник соціальної дезадаптації у пацієнтів 3 психічними розладами. Сучасні аспекти лікування психічних розладів : наук-практ. конф. 3 міжнар. участю (26-27 жовтня 2007 р). Чернівці, 2007. С. 110-113.

22. Горяча Т.С. Психологическая сущность понятия «соматогенная фрустрация». Науковий часопис НПУ імені М.П. Драгоманова. Серія 12. Психологічні науки : зб. наук. праць. Київ : НПУ імені М.П. Драгоманова, 2006. Вип. 11 (35). С. 84-89.

23. Карвасарский Б.Д. Клиническая психология: 2-е изд. Санкт-Петербург : Питер, 2007. 960 с.

24. Райгородский Д.Я. Практическая психодиагностика. Методики и тесты. Самара : Издательский дом «БАХРАХ-М», 2008. 672 c.

\section{REFERENCES}

1. Freud, S. (2010). Psihologiya bessoznatelnogo [Depth psychology]. Sankt-Petersburg: Piter [in Russian].

2. Berkovic, L. (2001). Agressiya: prichiny, posledstviya i kontrol [Agression: reasons, effects and control]. Sankt-Petersburg: Prajm-Evroznak [in Russian].

3. Hekhauzen, H. (1986). Motivaciya i deyatelnost: $v 2$ t. [Motivation and activity: in 2 vols.]. Moscow: Pedagogika, Vol. 1 [in Russian].

4. Cohen, A. (1955). Social norms, arbitrariness of frustrations, and status of the agent of frustration in the frustration-aggression hypothesis. Journal of Abnormal and Social Psychology, Vol. 51, No. 2, pp. 222-226.

5. Dushkov, B.A. (ed.) (2003). Psihologiya truda, professionalnoj, informacionnoj i organizacionnoj deyatelnosti (reklama, upravlenie, inzhenernaya psihologiya i ergonomika) [Psychology of labour, professional information and organizational activity (advertisement, management, engineering psychology and ergonomics)]. Moscow: Akademicheskij Proekt; Ekaterinburg: Delovaya kniga [in Russian]. 
6. Vasilyuk, F.E. (1984). Psihologiya perezhivaniya [Experience psychology]. Moscow: MGU [in Russian].

7. Maslow, A. (2006). Motivaciya i lichnost [Motivation and personality]. Sankt-Peterburg: Piter [in Russian].

8. Vasilyuk, F.E. (1984). Psihologiya perezhivaniya [Experience psychology]. Moscow: MGU [in Russian].

9. Maier, N.R.B. (1956). Frustration theory: restatement and extention. Psychological review, Vol. 63, No. 6, pp. 370-388.

10. Vasilyuk, F.E. (1984). Psihologiya perezhivaniya [Experience psychology]. Moskva: MGU [in Russian].

11. Lebedev, V.I. (1989). Lichnost $\mathrm{v}$ ekstremalnyh usloviyah [Personality under extreme conditions ]. Moscow: Politizdat [in Russian].

12. Izard, K. (2007). Psihologiya emocij [Psychology of emotions]. Sankt-Peterburg : Piter [in Russian].

13. Ganzen, V.A. (1984). Sistemnye opisaniya v psihologii [System descriptions in psychology]. Leningrad: Izdatelstvo Leningradskogo universiteta [in Russian].

14. Kulikov, L.V. (2000). Problema opisaniya psihicheskih sostoyanij. Psihicheskie sostoyaniya [Problem of describing psychological conditions. Mental states]. Saint-Petersburg: Piter [in Russian].

15. Levitov, N.D. (1964). O psihicheskih sostoyaniyah cheloveka [On human mental states]. Moscow: Prosveshenie [in Russian].

16. Myasishev, V.N. (1960). Lichnost i nevrozy [Personality and neuroses]. Leningrad: Izdatelstvo Leningradskogo universiteta [in Russian].

17. Maksymenko, K.S. (2011). Perezhyvannia nehatyvnykh psykhichnykh staniv osobystistiu [Experience of negative mental conditions by a personality]. Kyiv: KMM [in Russian].

18. Prohorov, A.O. (1991). Psihicheskie sostoyaniya i ih proyavleniya v uchebnom processe [Mental states and their manifestations during the learning activities]. Kazan: Izdatelstvo Kazanskogo universiteta [in Russian].

19. Sosnovikova, Yu.E. (1975). Psihicheskie sostoyaniya cheloveka, ih klassifikaciya i diagnostika [Human mental states, their classification and diagnostics]. Gorkij: GGPI im. A.M. Gorkogo.

20. Yurchenko, V.M. (2006) Psykhichni stany liudyny: systemnyi opys: monohrafiia [Human mental states: system description: a monograph]. Rivne: Operatyvna polihrafiia PP Samborskyi I.O. [in Ukrainian].

21. Prib, H.A. (2007). Frustratsiia yak chynnyk sotsialnoi dezadaptatsii u patsiientiv z psykhichnymy rozladamy [Frustration as a factor of the social maladjustment among mental patients]. Proceedings of the Suchasni aspekty likuvannia psykhichnykh rozladiv: nauk-prakt. konf. z mizhnar. uchastiu (October 26-27, 2007), Chernivtsi, pp. 110-113.

22. Horiacha, T.S. (2006). Psykholohycheskaia sushchnost poniatyia "somatohennaia frustratsyia" [Psychological essence of the concept "somatogenic frustration"]. Scientific journal of M.P. Dragomanov National Pedagogical University. Series 12. Psychological Sciences: Realities and Perspectives: a collection of scientific papers, Vol. 11 (35), pp. 84-89.

23. Karvasarskij, B.D. (2007). Klinicheskaya psihologiya: 2-e izd. [Clinical psychology: $2^{\text {nd }}$ ed.]. Saint-Petersburg: Piter [in Russian].

24. Rajgorodskij, D.Ya. (2008). Prakticheskaya psihodiagnostika. Metodiki i testy [Practical psychological assessment. Methods and tests]. Samara: Izdatelskij dom "BAHRAH-M" [in Russian]. 